\title{
PENGARUH KECUKUPAN MODAL, FUNGSI INTERMEDIASI, EFISIENSI OPERASIONAL, DAN PEMBIAYAAN BERMASALAH TERHADAP PROFITABILITAS (Studi pada Bank Syariah Periode Januari 2010 - Juli 2014) ${ }^{1)}$
}

\author{
Rifqul Ma'isyah \\ Mahasiswa Program Studi S1 Ekonomi Islam-Fakultas Ekonomi dan Bisnis- Universitas Airlangga \\ Email: bw.rifqulmaisyah@gmail.com \\ Imron Mawardi \\ Departemen Ekonomi Syariah-Fakultas Ekonomi dan Bisnis-Universitas Airlangga \\ Email: ronmawardi@gmail.com
}

\begin{abstract}
:
The research aims to analyze the influence of Capital Adequacy Ratio (CAR), Financing to Deposit Ratio (FDR), Opperational Efficiency (BOPO), and Non Performing Financing (NPF) to Return On Assets (ROA) of Sharia Banking in the period from January 2010 to July 2014. The sample population of the research is the Industry of Sharia Banking. Samples were taken by purposive sampling, which is taken from the Sharia Banking Industry. The analysis technique used in this research is by multiple linier regression that aims to obtain a comprehensive picture of the relationship between variables. The results of this research shows that the CAR, $B O P O$, and NPF have a significant influence on ROA of Sharia Banking. Whereas FDR has no significant influence on ROA of Sharia Banking. The amount of the contribution of the four variables on ROA is $47,20 \%$ while the remaining $52,80 \%$ influenced by other factors that are not included in the analysis of this research. The results of this research are expected to be guidelines for Sharia Banking in increasing the profitability of Sharia Banking.
\end{abstract}

\section{Keywords: CAR, FDR, BOPO, NPF, ROA}

\section{PENDAHULUAN}

Pertumbuhan ekonomi suatu bangsa memerlukan pola pengaturan dan pengelolaan sumber-sumber ekonomi secara terarah dan terpadu, serta dimanfaatkan bagi peningkatan kesejahteraan masyarakat. Lembagalembaga perekonomian mengelola dan menggerakkan semua potensi ekonomi agar berguna secara optimal. Khususnya lembaga perbankan mempunyai peranan yang strategis dalam menggerakkan roda perekonomian suatu negara.

Bank dalam menjalankan aktivitasnya berfungsi sebagai lembaga intermediasi (financial intermediary), yaitu lembaga keuangan yang berfungsi sebagai perantara pihak yang kelebihan dana dengan pihak yang kekurangan dana. Harta memiliki fungsi ekonomis yang harus senantiasa diberdayakan agar aktifitas ekonomi berjalan sehat. Maka harta harus berputar dan bergerak di kalangan masyarakat, baik dalam bentuk konsumsi atau investasi (Dendawijaya, 2005: 15).

Besarnya peranan bank dalam meningkatkan perekonomian di Indonesia, salah satunya adalah lahirnya bank syariah. Adanya bank syariah karena keinginan umat muslim untuk menjalankan aktivitas dalam perbankan sesuai dengan prinsip syariah. Dalam menjalankan kegiatan operasinya, bank 1) Jurnal ini merupakan bagian dari skripsi Rifqul Ma'isyah NIM : 041114162 , yang diuji pada 13 Februari 2015. 
syariah menggunakan sistem bagi hasil. Berbeda pada bank konvensional melaksankan kegiatan usahanya dengan menggunakan sistem bunga (riba) (Muhammad, 2014: 5).

Dalam Islam riba merupakan pengambilan keuntungan secara tidak sehat dalam sistem perekonomian. Riba juga menimbulkan kerugian salah satu pihak, dan hal itu haram hukumnya untuk dilakukan (Antonio, 2001: 37). Sebagaimana hal tersebut dijelaskan secara tersirat pada Al-Qur'an Surat Ali Imron ayat 130:

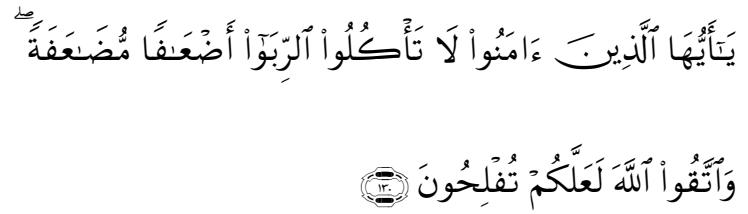

Ya> ayyuhallazli>na a>manu> la> ta'kulurriba> adf'a>fam mud\}a>'afataw wattaqulla $>$ ha la'allakum tuflih $\} u>n$.

Hai orang-orang yang beriman, janganlah kamu memakan riba dengan berlipat ganda dan bertakwalah kamu kepada Allah supaya kamu mendapat keberuntungan (Departemen Agama, 1989: 97).

Kehadiran bank syariah di tengahtengah masyarakat Indonesia kini sudah tidak dirasakan asing lagi. Dimulai sejak belasan tahun yang lalu ketika Bank Muamalat Indonesia mulai beroperasi sebagai bank syariah pertama di Indonesia. Belum banyak masyarakat merasakan kehadirannya waktu itu, karena cabangnya masih terbatas (Gozali, 2005: 1).
Kemampuan perusahaan dalam menghasilkan laba dapat menjadi tolak ukur kinerja perusahaan tersebut. Semakin tinggi profitabilitasnya, semakin baik pula kinerja keuangan perusahaan. Salah satu rasio yang digunakan untuk mengukur kinerja kevangan perbankan adalah Return On Assets (ROA) (Dendawijaya, 2005: 20).

Alasan dipilihnya industri bank syariah dalam penelitian ini, karena kegiatan bank diperlukan untuk lancarnya kegiatan perekonomian sektor riil, lebih dikhususkan pada profitabilitas bank. Hal tersebut karena penelitian tentang profitabilitas bank masih banyak research gap antara penelitian satu dengan penelitian yang lain. Oleh sebab itu perlu dilakukan penelitian Ianjutan untuk mendapatkan kejelasan.

Rasio yang digunakan dalam penelitian ini adalah Capital Adequacy Ratio (CAR) untuk mengukur kecukupan modal, Financing to Deposit Ratio (FDR) untuk mengukur fungsi intermediasi, rasio Biaya Operasional terhadap Pendapatan Operasional (BOPO) untuk mengukur efisiensi operasional, dan Non Performing Financing (NPF) untuk mengukur pembiayaan bermasalah.

Adapun dinamika pergerakan rasio keuangan perbankan syariah periode Januari 2010 sampai Juli 2014 ditunjukkan dalam Tabel 1.1 sebagai berikut: 
Tabel 1.

Data Rasio Keuangan Perbankan Syariah

Periode Januari 2010-Juli 2014

\begin{tabular}{|c|c|c|c|c|c|}
\hline $\begin{array}{c}\text { Indikator } \\
(\mathbf{\%})\end{array}$ & $\mathbf{2 0 1 0}$ & $\mathbf{2 0 1 1}$ & $\mathbf{2 0 1 2}$ & $\begin{array}{c}\mathbf{2 0 1 3} \\
\text { Juli }\end{array}$ & $\begin{array}{c}\mathbf{2 0 1 4} \\
\text { Juli }\end{array}$ \\
\hline ROA & 1,67 & 1,79 & 2,14 & 2,00 & 0,81 \\
\hline CAR & 16,25 & 16,63 & 14,13 & 14,17 & 16,63 \\
\hline FDR & 89,67 & 88,94 & 100,00 & 102,76 & 98,04 \\
\hline BOPO & 80,54 & 78,41 & 74,97 & 77,97 & 84,82 \\
\hline NPF & 3,02 & 2,52 & 2,2 & 2,87 & 23,68 \\
\hline
\end{tabular}

Sumber: Statistik Perbankan Syariah (SPS)

Pada tabel 1 diatas menjelaskan

secara empiris tampak bahwa rasio-rasio keuangan dari tahun ke tahun mengalami perubahan. Selain itu terdapat penyimpangan dengan teori yang menyatakan hubungan CAR, FDR, BOPO, dan NPF terhadap ROA.

Pada tahun 2012 ketika ROA naik menjadi 2,14\%, CAR justru mengalami penurunan sebesar 2,50\%. Namun sebaliknya, ketika ROA turun pada tahun 2013 dan 2014 masing-masing sebesar $2,00 \%$ dan $0,81 \%$, CAR justru mengalami naik sebesar $14,17 \%$ pada tahun 2013 dan $16,63 \%$ pada tahun 2014. Hal ini bersimpangan dengan teori yang menyatakan bahwa CAR berhubungan positif terhadap ROA.

Rasio FDR juga mengalami penyimpangan dengan teori yang ada. Ketika rasio FDR turun sebesar $0,73 \%$ pada tahun 2011, ROA justru naik sebesar 0,12\%. Namun sebaliknya, ketika rasio FDR naik sebesar 2,76\% pada tahun 2013, ROA justru turun sebesar $0,14 \%$. Sehingga ada kesan bahwa FDR berpengaruh negatif terhadap ROA. Sedangkan pada teorinya, dikatakan bahwa FDR berpengaruh positif terhadap ROA.

Dari fenomena gap di atas, dapat ditarik kesimpulan bahwa tidak setiap kejadian empiris sesuai dengan teori yang ada. Hal itu diperkuat oleh adanya research gap atau tidak terdapat konsistensi hasil dalam penelitian. Penelitian terdahulu yang dilakukan oleh Ariyani (2009), Nusantara (2009), Khatimah (2010), Suryani (2011), Widati (2012), dan Defri (2012). Dari fenomena gap dan research gap di atas, maka perlu dilakukan penelitian lebih lanjut mengenai pengaruh rasio CAR, FDR, BOPO, dan NPF terhadap ROA.

Berdasarkan uraian yang telah dijelaskan, maka peneliti dapat merumuskan masalah penelitian sebagai berikut: Apakah kecukupan modal, fungsi intermediasi, efisiensi operasional, dan pembiayaan bermasalah berpengaruh terhadap profitabilitas pada Bank Syariah secara simultan?, Apakah kecukupan modal, fungsi intermediasi, efisiensi operasional, dan pembiayaan bermasalah berpengaruh terhadap profitabilitas pada Bank Syariah secara parsial?

Sesuai dengan rumusan masalah diatas, maka tujuan penelitian dapat dirinci sebagai berikut: Untuk mengetahui pengaruh kecukupan modal, fungsi intermediasi, efisiensi operasional, dan pembiayaan bermasalah terhadap profitabilitas pada Bank Syariah secara simultan. Untuk mengetahui pengaruh kecukupan modal, fungsi intermediasi, efisiensi operasional, dan pembiayaan bermasalah terhadap profitabilitas pada Bank Syariah secara parsial. 


\section{LANDASAN TEORI}

\begin{abstract}
Bank syariah mempunyai fungsi yang berbeda dengan bank konvensional, fungsi bank syariah juga merupakan karakteristik bank syariah. Dalam fungsi bank syariah akan membawa dampak dalam pelaksanaan kegiatan usaha bank syariah (Wiroso, 2005: 4).
\end{abstract}

Profitabilitas atau kemampuan menghasilkan laba merupakan ukuran seberapa baik suatu sistem, berfungsi menurut besarnya laba yang berhasil dicetaknya (Molan, 2002: 123). Selain itu, profitabilitas juga dapat diartikan sebagai suatu ukuran dalam presentase, yang digunakan untuk menilai sejauh mana perusahaan menghasilkan laba pada tingkat yang dapat diterima (Simorangkir, 2003: 151). Dari kedua pendapat diatas dapat disimpulkan bahwa, profitabilitas merupakan suatu ukuran dalam presentase, yang digunakan untuk mengukur kemampuan perusahaan dalam menghasilkan laba, pada tingkat yang dapat diterima. Profitabilitas dalam dunia perbankan salah satunya dapat dihitung dengan Return On Assets (ROA). Return On Assets (ROA) merupakan rasio yang digunakan untuk mengukur kemampuan manajemen bank dalam mengelola aset untuk memperoleh keuntungan (laba) secara keseluruhan.

Kecukupan modal dapat dihitung dengan menggunakan rasio Capital Adequacy Ratio (CAR) adalah perbandingan antara total modal dengan aset tertimbang menurut risiko yang oleh
Bank Indonesia diterjemahkan menjadi KPMM (Kewajiban Penyediaan Modal Minimum) (Muhammad, 2014: 140). Tingginya CAR mencerminkan kemampuan bank dalam menanggung risiko yang mungkin timbul. Selain itu, menunjukkan kapabilitasnya dalam mengantisipasi adanya penurunan aktiva. Hal tersebut dengan tujuan untuk melindungi dana nasabah dan meningkatkan kepercayaan masyarakat (Muhammad, 2014: 151).

Fungsi intermediasi dapat dihitung dengan menggunakan rasio Financing to Deposit Ratio (FDR) merupakan rasio yang memperhitungkan antara DPK (Dana Pihak Ketiga) dengan kredit atau pembiayaan. FDR saat ini berfungsi sebagai salah satu indikator untuk menilai pelaksanaan fungsi intermediasi bank (Suhirman, 2001: 22). Rendahnya FDR menunjukkan kurangnya efektifitas bank dalam menyalurkan kredit atau pembiayaan. Jika rasio FDR bank berada pada standar yang ditetapkan oleh Bank Indonesia, maka laba yang diperoleh oleh bank tersebut akan meningkat. Dengan meningkatnya laba, maka ROA juga akan meningkat, karena laba merupakan komponen yang membentuk ROA.

Efisiensi operasional dapat dihitung dengan menggunakan rasio Beban Operasional terhadap Pendapatan Operasional (BOPO) adalah perbandingan antara biaya operasioanal dengan pendapatan operasional. BOPO digunakan untuk mengukur tingkat efisiensi dan kemampuan bank dalam 
melakukan kegiatan operasinya (Guinan, 2009: 110). Dengan tingginya biaya yang dikelvarkan dalam menghasilkan keuntungan yang dicapai bank, maka akan mengakibatkan rendahnya efisiensi operasional bank. Hal tersebut berpengaruh terhadap tingkat profitabilitas yang semakin menurun. Jika peningkatan biaya operasional bank mampu diiringi dengan kenaikkan pendapatan operasional yang lebih besar, maka akan berpengaruh terhadap kenaikkan ROA (Dendawijaya, 2005: 120).

Pembiayaan bermasalah dapat dihitung dengan menggunakan rasio Non Performing Financing (NPF) yang analog dengan Non Performing Loan (NPL) pada bank konvensional, merupakan rasio kevangan yang berkaitan dengan risiko kredit. Non Performing Financing (NPF) menunjukkan kemampuan manajemen bank dalam mengelola pembiayaan bermasalah yang diberikan bank. Pembiayaan bermasalah adalah pembiayaan dengan kualitas kurang lancar, diragukan, dan macet. Risiko kredit dengan NPF berpengaruh negatif terhadap kinerja keuangan bank yang dihitung dengan ROA. Sehingga semakin besar NPF, akan mengakibatkan menurunnya ROA.

\section{METODE PENELITIAN}

Pendekatan Penelitian

Pendekatan penelitian yang
digunakan dalam penelitian ini
merupakan pendekatan kuantitatif.
Penelitian ini menitik beratkan pada

pendekatan secara empiris dengan menggunakan statistik inferensial parametik, yang artinya setelah data dikumpulkan, maka dilakukan berbagai metode statistik untuk menganalisa data dan kemudian menginterpretasikan hasil analisa tersebut dengan memakai skala rasio. Skala rasio merupakan skala dimana angka mempunyai makna yang sesungguhnya (Santoso, 2000: 4).

\section{Identifikasi Variabel}

Dalam penelitian ini variabel-variabel yang digunakan sebagai berikut:

1. Variabel bebas (variabel independen) yang dibagi menjadi empat variabel, yaitu:

a. Kevukupan modal (CAR) $\left(\mathrm{X}_{1}\right)$

b. Fungsi intermediasi (FDR) $\left(\mathrm{X}_{2}\right)$

c. Efisiensi operasional (BOPO) $\left(\mathrm{X}_{3}\right)$

d. Pembiayaan bermasalah (NPF) $\left(\mathrm{X}_{4}\right)$

2. Variabel terikat (variabel dependen) yaitu: Profitabilitas (ROA) pada Bank Syariah ( $Y$ )

\section{Definisi Operasional Variabel}

Penelitian ini akan meneliti pengaruh kecukupan modal (CAR), fungsi intermediasi (FDR), efisiensi operasional (BOPO), dan pembiayaan bermasalah (NPF) terhadap profitabilitas (ROA) pada Bank Syariah. Untuk menjelaskan definisi tersebut, dalam memudahkan pengukuran terhadap masing-masing variabel, maka diperlukannya definisi 
operasional dalam variabel-variabel tersebut, maka sebagai berikut:

1. Return On Assets (ROA) ROA menunjukkan kemampuan manajemen bank dalam mengelola aset, untuk memperoleh keuntungan (laba) secara keseluruhan (Margaretha, 2007: 61). Variabel ROA merupakan variabel dependen dalam penelitian ini. Data ROA bersumber dari Statistik Perbankan Syariah (Rasio Kevangan pada Bank Syariah) periode Januari 2010 - Juli 2014 yang berjumlah 55 data. ROA diperoleh dari perhitungan laba sebelum pajak terhadap total aktiva.

2. Capital Adequacy Ratio (CAR).

CAR adalah rasio yang memperlihatkan seberapa jauh aktiva bank yang mengandung risiko (pembiayaan, penyertaan, surat berharga, dan tagihan pada bank lain) ikut dibiayai dari dana modal bank, disamping memperoleh dana-dana dari sumber-sumber diluar bank seperti dana masyarakat, pinjaman (utang), dan lain-lain (Margaretha, 2007: 63). Variabel CAR merupakan variabel independen dalam penelitian ini. Data CAR bersumber dari Statistik Perbankan Syariah (Rasio Kevangan pada Bank Syariah) periode Januari 2010-Juli 2014 yang berjumlah 55 data. CAR diperoleh dari perhitungan antara total modal terhadap aktiva tertimbang menurut risiko (ATMR).

3. Financing to Deposit Ratio (FDR) FDR adalah rasio yang memperhitungkan antara total pembiayaan yang diberikan dengan DPK (Dana Pihak Ketiga) dan ekuitas. Variabel FDR merupakan variabel independen dalam penelitian ini. Data FDR bersumber dari Statistik Perbankan Syariah (Rasio Keuangan pada Bank Syariah) periode Januari 2010-Juli 2014 yamg berjumlah 55 data. FDR diperoleh dari perhitungan total pembiayaan yang diberikan terhadap total dana pihak ketiga dan ekuitas.

4. Beban Operasional terhadap Pendapatan Operasional (BOPO) Salah satu alat yang dapat digunakan untuk mengukur efisiensi bank adalah rasio Beban Operasional terhadap Pendapatan Operasional (BOPO) (Guinan, 2009: 110). BOPO merupakan perbandingan antara biaya operasioanal dengan pendapatan operasional. Variabel BOPO merupakan variabel independen dalam penelitian ini. Data BOPO bersumber dari Statistik Perbankan Syariah (Rasio Kevangan pada Bank Syariah) periode Januari 2010-Juli 2014 yang berjumlah 55 data. BOPO diperoleh dengan cara 
membandingkan beban operasional dengan pendapatan operasional.

5. Non Performing Financing (NPF) Non Performing Loan (NPL) pada bank konvensional dan Non Performing Financing (NPF) pada bank syariah, merupakan risiko yang terkandung dalam setiap pemberiaan pembiayaan atau kredit oleh bank (Nasution, 2006: 154). NPF menunjukkan kemampuan manajemen bank dalam mengelola pembiayaan bermasalah yang diberikan bank. Variabel NPF merupakan variabel independen dalam penelitian ini. Data NPF bersumber dari Statistik Perbankan Syariah (Rasio Keuangan pada Bank Syariah) periode Januari 2010-Juli 2014 yang berjumlah 55 data. NPF diperoleh dengan cara membandingkan antara pembiayaan non lancar $(K L, D, M)$ dengan total pembiayaan.

\section{Jenis dan Sumber Data}

Dalam melaksanakan penelitian ini, data yang dipergunakan adalah data sekunder yang berupa rasio keuangan pada Bank Syariah. Data yang dipergunakan dalam penelitian ini merupakan data sekunder yang diperoleh dari Statistik Perbankan Syariah (SPS). Data tersebut diterbitkan dalam website resmi Bank Indonesia dan website resmi Otoritas Jasa Keuangan (OJK). Periode data menggunakan Statistik Perbankan Syariah
(Rasio Kevangan pada Bank Syariah) periode Januari 2010-Juli 2014.

\section{Populasi dan Sampel Penelitian}

Populasi dalam penelitian ini adalah industri bank syariah. Dimana populasi dalam penelitian ini diambil dari periode Mei 1992-Juli 2014 yang berjumlah 252 bulan. Sehingga populasi dalam penelitian ini berjumlah 252. Sampel dalam penelitian ini diambil secara sengaja (purposive sampling), jadi sampel diambil tidak secara acak tetapi ditentukan sendiri oleh peneliti. Sampel diambil secara purposive sampling, yang diambil dari industri bank syariah pada tabel Statistik Perbankan Syariah (SPS) periode Januari 2010-Juli 2014 yang berjumlah 55 bulan. Sehingga sampel pada penelitian ini adalah $55(n=55)$.

\section{Prosedur Pengumpulan Data}

Prosedur pengumpulan data dilakukan melalui studi pustaka dengan mengkaji buku - buku literatur, jurnal, makalah, dan sumber-sumber lainnya yang berkaitan dengan penelitian. Hal itu, dengan tujuan untuk memperoleh landasan teoritis secara komprehensif (mudah diterima atau dipahami) terkait industri perbankan syariah. Dalam prosedur pengumpulan data juga dilakukan metode dokumentasi terhadap data Statistik Perbankan Syariah (SPS) dalam rasio keuangan Bank Syariah, yang diterbitkan dalam website resmi Bank Indonesia dan website resmi Otoritas Jasa Keuangan (OJK).

\section{Teknik Analisis}


Teknik analisis yang digunakan dalam penelitian ini adalah regresi linier berganda dengan time series. Adapun alat analisis yang digunakan adalah analisis regresi linier berganda, dengan melakukan uji asumsi klasik terlebih dahulu.

\section{Uji Asumsi Klasik}

Sebelum dilakukan uji regresi linier berganda, akan dilakukan uji asumsi klasik terlebih dahulu, sebagai berikut:

1. Multikolinieritas

Multikolinieritas merupakan situasi multi korelasi diantara variabel independen satu dengan lainnya atau diantara variabel-variabel independen tersebut. Data dibentuk hubungan antara variabel satu dengan variabel yang lain. Uji multikolinieritas dilakukan dengan mencari nilai Variance Inflation Factor (VIF) dan nilai Tolerance pada tabel Coefficient output statistik. Jika nilai VIF kurang dari 10 dan nilai dari tolerance lebih dari 0,1 maka regresi bebas dari multikolinieritas (Santoso, 2000: 214).

2. Heteroskedatisitas Heteroskedatisitas merupakan situasi terjadinya ketidaksamaan varians residual dari satu pengamatan ke pengamatan yang lain. Cara mendeteksi heteroskedatisitas adalah dengan melihat ada atau tidaknya pola tertentu pada Scatter Plot yang terdapat dalam output statistik. Jika tidak ada pola yang jelas, serta titik-titik menyebar diatas dan dibawah angka 0 pada sumbu $Y$, maka tidak terjadi heteroskedatisitas (Sujarweni, 2014: 186).

3. Autokorelasi

Autokorelasi merupakan situasi dimana adanya korelasi antara kesalahan pengganggu pada suatu priode ( $\dagger$ ), dengan kesalahan pengganggu pada periode sebelumnya (t-1). Untuk mendeteksi ada tidaknya autokorelasi dengan melihat nilai dari D-W (Durbin - Watson) pada tabel Model Summary output statistik (Santoso, 2000: 144).

Mendeteksi autokorelasi dengan menggunakan nilai Durbin-Watson dengan cara menentukan atau kriteria pengujian autokorelasi sebagai berikut:

a. Besaran D-W di bawah -2 berarti adanya autokorelasi

b. Besaran D-W di atas +2 berarti tidak adanya autokorelasi.

4. Uji Normalitas

Uji normalitas adalah untuk menentukan apakah variabel berdistribusi normal atau tidak. Uji normalitas bertujuan untuk mengetahui distribusi data dalam variabel yang akan digunakan dalam penelitian. Data yang baik dan layak digunakan dalam 


penelitian adalah data yang
memiliki distribusi normal.
Normalitas data dapat dilihat
dengan menggunakan uji normal
Kolmogorov-Smirnov (Sujarweni,
2014: 52). Dalam menentukan
data berdistribusi normal, adanya
dasar pengambilan keputusan uji
normalitas, sebagai berikut:
a. Data berdistribusi normal,
jika nilai sig (signifikansi) >
0,05 . Data berdistribusi tidak
b. jormal, jika nilai sig
(signifikansi) < 0,05.

\section{Analisis Regresi Linier Berganda}

Metode analisis statistik dalam penelitian ini menggunakan teknik analisis regresi linier berganda. Adapun model dari regresi linier berganda, yaitu sebagai berikut:

$Y=a+b_{1} X_{1}+b_{2} X_{2}+b_{3} X_{3}+b_{4} X_{4}+e$

Agar dapat menginterpretasikan hasil regresi dengan benar, dibutuhkan pengujian statistik yang relevan, diantaranya pengujian secara simultan (Uji F) dan pengujian secara parsial (Uji t), dijelaskan sebagai berikut:

1. Uji F

Uji $F$ digunakan untuk menguji apakah variabel bebas secara simultan atau bersama - sama berpengaruh signifikan terhadap variabel terikat. Prosedur dari Uji F (secara simultan) adalah sebagai berikut (Rochaety, 2007: 119):

Hipotesis:

$\mathrm{H}_{\mathrm{o}}=\mathrm{b}_{1} \mathrm{~b}_{1}=\cdots=\mathrm{b}_{\mathrm{i}}=0$
$\mathrm{H}_{\mathrm{a}}=$ minimal ada salah satu $\mathrm{b}_{\mathrm{i}} \neq 0$

a. Membandingkan $F$ hitung dengan $\mathrm{F}$ tabel.

- Jika $F$ hitung $>F$ tabel maka $\mathrm{H}_{\circ}$ ditolak dan $\mathrm{H}_{\mathrm{a}}$ diterima.

- Jika $F$ hitung<F tabel maka $\mathrm{H}_{\circ}$ diterima dan $\mathrm{H}_{\mathrm{a}}$ ditolak.

F hitung dapat dilihat dari tabel ANOVA output statistik, sedangkan $F$ tabel didapat dari tabel F. Cara mencari nilai $F$ tabel yaitu dengan cara menghitung numerator $\left(\mathrm{df}_{1}=\mathrm{k}-1\right)$ dan denumerator $\left(\mathrm{df}_{2}=n-k\right)$, serta derajat kebebasan (a) yang digunakan, dimana $k$ adalah jumlah variabel dan $n$ adalah jumlah sampel yang diteliti.

b. Membandingkan taraf signifikan (sig.) penelitian dengan taraf signifikansi (a) sebesar 0,05 (5\%).

- Sig. penelitian < 0,05 maka $\mathrm{H}_{\mathrm{o}}$ ditolak dan $\mathrm{H}_{\mathrm{a}}$ diterima.

- Sig. penelitian >0,05 maka $\mathrm{H}_{\circ}$ diterima dan $\mathrm{H}_{\mathrm{a}}$ ditolak.

Nilai sig. penelitian dapat diperoleh dengan melihat tabel ANOVA output statistik. Jika $\mathrm{H}_{\mathrm{o}}$ ditolak, minimal ada satu variabel bebas yang berpengaruh signifikan terhadap variabel terikat dan 
model layak digunakan. Jika $\mathrm{H}_{\mathrm{o}}$ diterima, maka tidak ada satu pun variabel bebas yang berpengaruh signifikan terhadap variabel terikatnya.

2. $U j i \dagger$

Uji † digunakan untuk menguji tingkat signifikan masing-masing variabel bebas secara individu terhadap variabel terikat. Uji † juga dapat dijelaskan sebagai pengujian yang dilakukan untuk mengetahui apakah variabel bebas secara parsial berpengaruh signifikan terhadap variabel terikat. Pengujian ini ditujukan untuk mengetahui tingkat signifikansi variabel bebas, dengan hipotesis:

- $\mathrm{H}_{\mathrm{o}}=$ koefisien model regresi tidak singfikan

- $\mathrm{H}_{\mathrm{a}}=$ koefisien model regresi singfikan

Berikut ini merupakan prosedur dari Uji † (secara parsial) adalah (Rochaety, 2007:115):

a. Membandingkan $\dagger$ hitung dengan $t$ tabel.

- Jika t hitung > t tabel maka $\mathrm{H}_{\circ}$ ditolak dan $\mathrm{H}_{\mathrm{a}}$ diterima.

- Jika † hitung < † tabel maka $\mathrm{H}_{\mathrm{o}}$ diterima dan $\mathrm{H}_{\mathrm{a}}$ ditolak $T$ hitung dapat dilihat pada tabel Coefficient output statistik, sedangkan $t$ tabel yaitu menentukan taraf signifikan 0,05 dan menghitung besarnya derajat

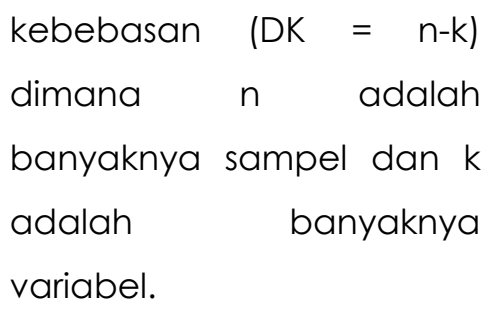

b. Membandingkan taraf signifikan (sig.) penelitian dengan taraf signifikansi (a) sebesar 0,05 (5\%).

- Sig. penelitian >0,05 maka $\mathrm{H}_{\circ}$ diterima dan $\mathrm{H}_{\mathrm{a}}$ ditolak.

- Sig. penelitian < 0,05 maka $\mathrm{H}_{\circ}$ ditolak dan $\mathrm{H}_{a}$ diterima

Nilai sig. penelitian bisa dilihat pada tabel Coefficient output statistik. Jika $\mathrm{H}_{\mathrm{o}}$ ditolak, maka variabel bebas secara parsial berpengaruh signifikan terhadap variabel terikat. Sebaliknya $\mathrm{H}_{\mathrm{o}}$ diterima berarti variabel bebas secara parsial tidak berpengaruh signifikan terhadap variabel terikat.

\section{HASIL DAN PEMBAHASAN}

\section{Deskripsi Hasil Penelitian}

Data-data yang diperlukan dalam hasil analisis ini didapat dari Statistik Perbankan Syariah (Rasio Kevangan pada Bank Syariah) periode Januari 2010-Juli 2014 sebanyak 55 data. Hasil olah data dalam penelitian ini dilakukan dengan menggunakan SPSS Statistics version 20.

Sebelum melakukan pengujian signifikansi terhadap hipotesis dan fungsi regresi linier berganda, akan dilakukan pengujian asumsi klasik terlebih dahulu.

\section{Uji Multikolinieritas}


Hasil pengujian multikolinieritas dalam penelitian ini dengan menggunakan SPSS Statistics version 20 yang ditunjukkan dalam tabel sebagai berikut:

Tabel 2.

Uji Multikolinieritas Coefficientsa

\begin{tabular}{|c|c|c|c|}
\hline \multirow{2}{*}{\multicolumn{2}{|c|}{ Model }} & \multicolumn{2}{|c|}{ Collinearity Statistics } \\
\hline & & Tolerance & VIF \\
\hline 1 & (Constant) & & \\
\hline & CAR & 0,917 & 1,090 \\
\hline & FDR & 0,799 & 1,252 \\
\hline & BOPO & 0,805 & 1,242 \\
\hline & NPF & 0,787 & 1,270 \\
\hline
\end{tabular}

a. Dependent Variable: ROA

Sumber: Data olahan SPSS Statistics version 20

Pada tabel hasil uji multikolinieritas terlihat bahwa angka VIF untuk variabel CAR sebesar 1,090, variabel FDR sebesar 1,252, variabel BOPO sebesar 1,242, dan variabel NPF sebesar 1,270. Pada tabel tersebut terlihat bahwa semua nilai VIF dari keempat variabel kurang dari 10.

Pada tabel hasil uji multikolinieritas juga menunjukkan nilai tolerance dengan variabel CAR sebesar 0,917, variabel FDR sebesar 0,799, variabel BOPO sebesar 0,805, dan variabel NPF sebesar 0,787. Semua nilai tolerance dari keempat variabel lebih dari 0,1 .

Pada bagian Coefficients, diketahui bahwa nilai VIF dari masingmasing variabel independen kurang dari 10 dan pada nilai tolerance dari masingmasing variabel lebih dari 0,1. Data-data di atas dapat disimpulkan bahwa di antara variabel independen tersebut tidak ada korelasi atau tidak terjadi multikolinieritas pada model regresi linier.

\section{Uji Heteroskedatisitas}

Hasil pengujian heteroskedatisitas dalam penelitian ini dengan menggunakan SPSS Statistics version 20 yang ditunjukkan dalam gambar sebagai berikut:

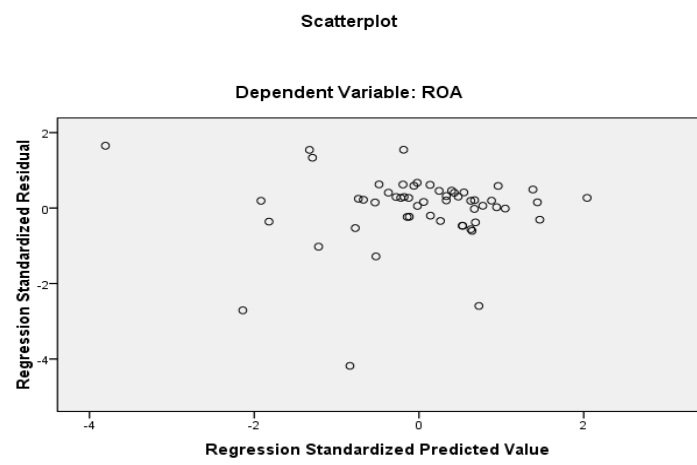

Gambar 1.

Hasil Uji Heteroskedatisitas

Dari hasil uji heteroskedatisitas, terlihat titik-titik yang menyebar secara acak, dan tidak membentuk suatu pola tertentu yang jelas. Titik-titik tersebut menyebar baik diatas maupun dibawah angka 0 pada sumbu $Y$. Hal ini menunjukkan tidak terjadi heteroskedatisitas pada model regresi linier berganda ini. Model regresi linier berganda layak dipakai untuk memprediksi Return On Assets (ROA) terhadap variabel independen lainnya.

\section{Uji Autokorelasi}

Hasil pengujian autokorelasi dalam penelitian ini dengan menggunakan SPSS Statistics version 20 yang ditunjukkan dalam tabel sebagai berikut: 
Tabel 3.

Hasil Uji Autokorelasi

Model Summaryb

\begin{tabular}{|r|c|r|r|}
\hline Model & $\mathrm{R}$ & $\begin{array}{c}\text { Std. Error } \\
\text { of the } \\
\text { Estimate }\end{array}$ & Durbin-Watson \\
\hline 1 & $0,687^{\mathrm{a}}$ & 0,34485 & 2,108 \\
\hline
\end{tabular}

a. Predictors: (Constant), NPF, CAR, BOPO, FDR

b. Dependent Variable: ROA

Sumber: Data olahan SPSS Statistics version 20

Terlihat pada tabel di atas bahwa nilai Durbin-Watson yang diperoleh dari hasil analisis regresi linier berganda sebesar 2,108. Hal ini menunjukkan bahwa angka Dubin-Watson (DW) diantara -2 < DW < +2, maka model regresi linier berganda tidak terdapat masalah autokorelasi dan bebas dari autokorelasi dan model ini layak untuk digunakan.

\section{Uji Normalitas}

Hasil pengujian normalitas dalam penelitian ini dengan menggunakan SPSS Statistics version 20 yang ditunjukkan dalam tabel sebagai berikut:

Tabel 4.

Hasil Uji Normalitas

One-Sample Kolmogorov-Smirnov Test

\begin{tabular}{|ll|r|}
\hline Normal Parametersa,b & Mean & $\begin{array}{r}\text { Unstandardized } \\
\text { Residual }\end{array}$ \\
\hline Most Extreme Differences & Std. & 0,0000000 \\
& Deviation & 0,33183086 \\
& Absolute & 0,182 \\
Kolmogorov-Smirnov Z & Positive & 0,170 \\
Asymp. Sig. (2-tailed) & Negative & $-0,182$ \\
& & 1,353 \\
\hline
\end{tabular}

a. Test distribution is Normal

b. Calculated from data

Sumber: Data olahan SPSS Statistics version 20

Berdasarkan uji normalitas dengan Kolmogorov-Smirnov Test diperoleh nilai
Kolmogorov-Smirnov Z (KSZ) sebesar 1,353 dan Asymp. Sig (2-tailed) sebesar 0,051 lebih besar dari 0,05. Dapat disimpulkan bahwa data tersebut berdistribusi normal atau sebaran data normal.

\section{Analisis Regresi Linier Berganda}

Adapun model yang terbentuk dari regresi linier berganda dari tabel coefficient output statistik, sebagai berikut: $\mathrm{ROA}=11,447-0,072 \mathrm{CAR}-0,022$ FDR $0,075 \mathrm{BOPO}-0,172 \mathrm{NPF}$

Agar dapat menginterpretasikan hasil regresi dengan benar, dibutuhkan pengujian hipotesis dan statistik yang relevan, diantaranya pengujian secara simultan (Uji F) dan pengujian secara parsial (Uji †).

\section{Uji F (secara simultan)}

Hasil Uji F (secara simultan) dalam penelitian ini dengan menggunakan SPSS Statistics version 20 yang ditunjukkan dalam tabel sebagai berikut:

Tabel 5.

Hasil Uji $F$

ANOVAa

\begin{tabular}{|l|r|r|r|r|r|}
\hline Model & $\begin{array}{c}\text { Sum of } \\
\text { Squares }\end{array}$ & df & $\begin{array}{c}\text { Mean } \\
\text { Square }\end{array}$ & \multicolumn{1}{c|}{$\mathrm{F}$} & Sig. \\
\hline $1 \quad \begin{array}{l}\text { Regressi } \\
\text { on }\end{array}$ & 5,326 & 4 & 1,331 & 11,196 & 0,0000 \\
$\begin{aligned} \text { Residual } \\
\text { Total }\end{aligned}$ & 5,946 & 50 & 0,119 & & \\
11,272 & 54 & & & \\
\hline
\end{tabular}

a. Predictors: (Constant), NPF, CAR, BOPO, FDR

b. Dependent Variable: ROA

Sumber: Data olahan SPSS Statistics version 20

Dari tabel hasil Uji F, terlihat bahwa nilai $F$ hitung adalah sebesar 11,196. Sedangkan $\mathrm{F}$ tabel didapat dengan cara menghitung:

Numerator $\left(\mathrm{df}_{1}=\mathrm{k}-1\right) \rightarrow 5-1=4$

Denumerator $\left(\mathrm{df}_{2}=\mathrm{n}-\mathrm{k}\right) \rightarrow 55-5=50$ 
Derajat kebebasan $(a)=0,05$

Maka nilai $F$ tabel $=2,56$

Dari perhitungan nilai $F$ diketahui bahwa $F$ hitung $(11,196)>F$ tabel $(2,56)$, maka Ha diterima dan Ho ditolak. Hasil dari uji $F$ juga menunjukkan bahwa semua angka signifikan, karena tingkat probabilitas sig 0,000 . Nilai probabilitas $(0,000)$ lebih kecil dari 0,05. Dengan demikian, secara statistik dapat disimpulkan bahwa CAR, FDR, BOPO, dan NPF secara bersama-sama (secara simultan) berpengaruh signifikan terhadap ROA pada Bank Syariah.

\section{Uji † (secara parsial)}

Hasil Uji † (secara parsial) dalam penelitian ini dengan menggunakan SPSS Statistics version 20 yang ditunjukkan dalam tabel sebagai berikut:

Tabel 6.

Hasil Uji $\dagger$

Coefficientsa

\begin{tabular}{|ll|r|r|r|}
\hline \multirow{2}{*}{ Model } & & \multicolumn{3}{|c|}{ Unstandardized Coefficients } \\
\cline { 2 - 5 } & (Constant) & 11,447 & \multicolumn{1}{c|}{ B } & \multicolumn{1}{c|}{ Sig } \\
\hline 1 & CAR & $-0,072$ & -000 \\
& CAR & -640 & 0,011 \\
FDR & $-0,022$ & $-1,976$ & 0,054 \\
BOPO & $-0,075$ & $-5,252$ & 0,000 \\
& NPF & $-0,172$ & $-2,136$ & 0,038 \\
\hline
\end{tabular}

a. Dependent Variable: ROA

Sumber: Data olahan SPSS Statistics version 20

Uji $\dagger$ (secara parsial) digunakan untuk mengetahui hubungan masingmasing masing variabel independen (CAR, FDR, BOPO, dan NPF) secara individual atau secara parsial terhadap variabel dependen (ROA). Berdasarkan pengujian pada tabel hasil uji † (secara parsial), maka dapat disimpulkan sebagai berikut: a. Pengaruh variabel CAR terhadap ROA

Nilai † hitung untuk variabel CAR sebesar $-2,640$, sedangkan $\dagger$ tabel untuk taraf signifikansi 0,05 dengan derajat kebebasan (DK = $n-k \rightarrow 55-5=50$ ) adalah sebesar 2,009 . Dari perhitungan nilai † untuk variabel CAR diketahui bahwa nilai t hitung $(-2,640)>$ t tabel $(-2,009)$, maka Ha diterima dan Ho ditolak. Nilai probabilitas (sig. penelitian) untuk variabel $\operatorname{CAR}(0,011)<0,05$, maka Ha diterima dan Ho ditolak. Dapat disimpulkan bahwa secara statistik CAR secara parsial berpengaruh signifikan terhadap ROA pada Bank Syariah periode Januari 2010-Juli 2014.

b. Pengaruh variabel FDR terhadap ROA

Nilai † hitung untuk variabel FDR sebesar -1,976, sedangkan † tabel untuk taraf signifikansi 0,05 dengan derajat kebebasan (DK = $\mathrm{n}-\mathrm{k} \rightarrow 55-5=50$ ) adalah sebesar 2,009 . Dari perhitungan nilai $\dagger$ untuk variabel FDR diketahui bahwa nilai t hitung $(-1,976)<$ tabel $(-2,009)$, maka Ha ditolak dan Ho diterima. Nilai probabilitas (sig. penelitian) untuk variabel $\operatorname{FDR}(0,054)>0,05$, maka Ha ditolak dan Ho diterima. Dapat disimpulkan bahwa secara statistik FDR secara parsial tidak berpengaruh signifikan terhadap tingkat ROA pada Bank Syariah periode Januari 2010-Juli 2014. 
c. Pengaruh variabel BOPO terhadap ROA

Nilai † hitung untuk variabel BOPO sebesar $-5,252$, sedangkan † tabel untuk taraf signifikansi 0,05 dengan derajat kebebasan (DK = $n-k \rightarrow 55-5=50$ ) adalah sebesar 2,009 . Dari perhitungan nilai † untuk variabel BOPO diketahui bahwa nilai $\dagger$ hitung $(-5,252)>+$ tabel $(-$ 2,009), maka Ha diterima dan Ho ditolak. Nilai probabilitas (sig. penelitian) untuk variabel BOPO $(0,000)<0,05$, maka Ha diterima dan Ho ditolak. Dapat disimpulkan bahwa secara statistik BOPO secara parsial berpengaruh signifikan terhadap tingkat ROA pada Bank Syariah periode Januari 2010-Juli 2014.

d. Pengaruh variabel NPF terhadap ROA

Nilai † hitung untuk variabel NPF sebesar -2,136, sedangkan † tabel untuk taraf signifikansi 0,05 dengan derajat kebebasan (DK = $n-k \rightarrow 55-5=50$ ) adalah sebesar 2,009 . Dari perhitungan nilai $\dagger$ untuk variabel CAR diketahui bahwa nilai t hitung $(-2,136)>$ t tabel $(-2,009)$, maka Ha diterima dan Ho ditolak. Nilai probabilitas (sig. penelitian) untuk variabel $\operatorname{NPF}(0,038)<0,05$, maka Ha diterima dan Ho ditolak. Dapat disimpulkan bahwa secara statistik NPF secara parsial berpengaruh signifikan terhadap tingkat ROA pada Bank Syariah periode Januari 2010-Juli 2014.

\section{Koefisien Determinasi ( $\left.\mathbf{R}^{\mathbf{2}}\right)$}

Dalam penelitian ini, perhitungan koefisien determinasi $\left(R^{2}\right)$ dilakukan untuk mengetahui seberapa besar kontribusi variabel independen (CAR, FDR, BOPO, dan NPF) berpengaruh terhadap variabel dependen (ROA). Angka koefisien determinasi $\left(R^{2}\right)$ dapat dilihat pada tabel model summary output statistik.

Hasil koefisien determinasi ( $\left.\mathrm{R}^{2}\right)$ dalam penelitian ini dengan menggunakan SPSS Statistics version 20 yang ditunjukkan dalam tabel sebagai berikut:

Tabel 7.

Hasil Koefisien Determinasi $\left(\mathrm{R}^{2}\right)$ Model Summaryb

\begin{tabular}{|l|r|r|c|}
\hline Model & $R$ & R Square & $\begin{array}{c}\text { Adjusted R } \\
\text { Square }\end{array}$ \\
\hline 1 & 0,6879 & 0,472 & 0,430 \\
\hline
\end{tabular}

a. Predictors: (Constant), NPF, CAR, BOPO, FDR

b. Dependent Variable: ROA

Sumber: Data olahan SPSS Statistics version 20

Pada tabel hasil koefisien determinasi $\left(R^{2}\right)$ sebesar 0,472. Angka tersebut menunjukkan bahwa variabel ROA dapat dijelaskan oleh variabel CAR, FDR, BOPO, dan NPF sebesar 47,20\%. Dengan kata lain, secara statistik besarnya kontribusi pengaruh kecukupan modal (CAR), fungsi intermediasi (FDR), efisiensi operasional (BOPO), dan pembiayaan bermasalah (NPF) terhadap perubahan tingkat profitabilitas (ROA) pada Bank Syariah periode Januari 2010Juli 2014 adalah sebesar 47,20\%, dan 
sisanya sebesar $52,80 \%$ dipengaruhi oleh faktor-faktor lain yang tidak dimasukkan dalam penelitian ini.

\section{KESMIPULAN DAN SARAN}

\section{KESIMPULAN}

Berdasarkan hasil penelitian mengenai pengaruh kecukupan modal, fungsi intermediasi, efisiensi operasional, dan pembiayaan bermasalah terhadap profitabilitas pada Bank Syariah periode Januari 2010-Juli 2014, maka dapat ditarik beberapa simpulan sebagai berikut:

1. Berdasarkan hasil uji $F$ statistik (secara simultan) dengan taraf signifikansi (a) sebesar 0,05, menunjukkan bahwa secara statistik dapat disimpulkan bahwa kecukupan modal (CAR), fungsi intermediasi (FDR), efisiensi operasional (BOPO), dan pembiayaan bermasalah (NPF) secara simultan berpengaruh signifikan terhadap profitabilitas (ROA) pada Bank Syariah periode Januari 2010-Juli 2014.

2. Berdasarkan hasil uji $\dagger$ statistik (secara parsial) menunjukkan bahwa kecukupan modal (CAR), efisiensi operasional (BOPO), dan pembiayaan bermasalah (NPF) berpengaruh signifikan terhadap ROA pada Bank Syariah periode Januari 2010-Juli 2014. Sedangkan fungsi intermediasi (FDR) tidak berpengaruh signifikan terhadap profitabilitas (ROA) pada Bank
Syariah periode Januari 2010-Juli 2014.

Menurut analisis regresi antara kecukupan modal (CAR), fungsi intermediasi (FDR), efisiensi operasion al (BOPO), dan pembiayaan bermasalah (NPF)yang menjadi variabel paling dominan adalah Non Performing Financing (NPF) atau pembiayaan bermasalah. Hal ini terlihat dalam output sebagai berikut, $\mathrm{ROA}=11,447-0,072$ CAR - 0,022 FDR - 0,075 BOPO - 0,172 NPF. Persamaan tersebut mengasumsikan bahwa jika pengaruh FDR, BOPO, dan NPF konstan, maka kenaikan sebesar satusatuan CAR akan menyebabkan penurunan ROA sebesar -0,072 satuan. Apabila pengaruh CAR, BOPO, dan NPF konstan, maka kenaikan sebesar satu satuan FDR akan menyebabkan penurunan ROA sebesar -0,022 satuan. Apabila pengaruh CAR, FDR, dan NPF konstan, maka kenaikan sebesar satusatuan BOPO akan menyebabkan penurunan ROA sebesar -0,075 satuan. Apabila pengaruh CAR, FDR, dan BOPO konstan, maka kenaikan sebesar satusatuan NPF akan menyebabkan penurunan ROA sebesar -0,172 satuan.

\section{SARAN}

Saran yang diajukan berdasarkan hasil penelitian yang sudah diperoleh adalah sebagai berikut:

1. Untuk Perbankan Syariah

a. Dalam mengurangi faktor penyebab terjadinya pembiayaan bermasalah atau Non Performing Financing 
(NPF), yang harus dilakukan adalah pengenalan terhadap karakter debitur secara lebih mendalam dan melakukan analisa secara komprehensif terhadap prospek usaha debitur dengan melakukan studi kelayakan terutama bagi debitur yang mepunyai risiko tinggi, debitur bermasalah, atau debitur yang mempunyai kondite tidak baik dalam daftar Sistem Informasi Debitur (SID) yang dibuat oleh Bank Indonesia.

b. Melakukan monitoring secara rutin terhadap para nasabah, agar dapat mempersempit celah dari penyimbangan penggunaan pembiayaan.

2. Untuk Penelitian Selanjutnya

$$
\text { Penelitian ini dapat }
$$
dijadikan bahan acuan untuk penelitian selanjutnya, dengan memasukkan lebih banyak variabel-variabel lain diluar variabel ini, agar memperoleh hasil yang lebih bervariatif yang dapat menggambarkan hal-hal yang dapat berpengaruh terhadap ROA, dan dapat memperpanjang periode pengamatan.

\section{DAFTAR PUSTAKA}

Al-Qur'an dan Terjemahannya (Transliterasi) Departemen Agama RI. 1989. Surabaya. Mahkota.
Antonio, Muhammad Syafi'i. 2001. Bank Syariah: Dari Teori ke Praktik. Jakarta: Gema Insani Press.

Ariyani, Desi. 2009. "Analisis Pengaruh CAR, FDR, BOPO, dan NPF terhadap Profitabilitas pada PT Bank Muamalat Indonesia Tbk Periode Januari 2005-April 2008". Universitas Islam Negeri Syarif Hidayatullah Jakarta.

Defri. 2012. Pengaruh Capital Adequacy Ratio (CAR), Likuiditas, dan

EfisiensiOperasionalterhadapProfita bilitas Perusahaan Perbankan yang Terdaftar di BEI. JurnalManajemen, Vol. 01 , No. 01.

Dendawijaya, Lukman. 2005. ManajemenPerbankan. Bogor: Ghalia Indonesia.

Gozali, $\quad 2005$. JanganadaBungadiantara Kita: Serba-serbiKreditSyariah. Jakarta: Elex Media Komputindo.

Guinan, Jack. 2009. Investopedia: Cara Mudah Memahami ilstilah Investasi. Jakarta: Hikmah.

Khatimah, Ima. 2010. "Pengaruh Kecukupan Modal dan Efisiensi Operasional terhadap Profitabilitas pada PT BPRS Amanah Ummah Leuwiliang Bogor". Universitas Islam Negeri Syarif Hidayatullah Jakarta. Margaretha, Farah. 2007. Manajemen Keuangan bagi Industri Jasa. Jakarta: Grasindo.

Molan, Benyamin. 2002. Glosarium Prentice hall untuk Manajemen 
dan Pemasaran. Jakarta: Keuangan dan Perbankan, Vol. 19, Prenhallindo. No. 1.

Muhammad. 2014. Manajemen Dana Widati, Listyorini Wahyu. 2012. Analisis Bank Syariah. Jakarta: PT Raja Grafindo Persada.

Nasution, lur Adnan Buyuung. 2006.

Panduan Bantuan Hukum di Indonesia. Jakarta: YLBHI dan PSHK Indeks.

Nusantara, Ahmad Buyung. 2009. "Analisis Pengaruh NPL, CAR, LDR, dan BOPO terhadap Profitabilitas Bank (Perbandingan Bank Umum Go Publik dan Bank Umum Non Go Publik di Indonesia Periode 20052007)". Tesis Program Pasca Sarjana Magister Manajemen Universitas Diponegoro.

Santoso, Singgih. 2000. Latihan SPSS Statistik Parametrik. Jakarta: PT Elex Media Komputindo.

Simorangkir, O. P. 2003. Analisis Kinerja Kevangan dan Kinerja Kevangan Perusahaan. Bogor: Ghalia Indonesia.

Suhirman. 2001. Kajian tentang Perkembangan LDR dan Dampaknya bagi Rentabilitas Bank. Jakarta: Institut Bankir Indonesia.

Sujarweni, V. Wiratna. 2014. SPSS Untuk Penelitian. Yogyakarta: Pustaka Baru Press.

Suryani.2011. Analisis Pengaruh Financing to Deposit Ratio (FDR) terhadap Profitabilitas Perbankan Syariah di Indonesia. Jurnal 